ToSEE - Tourism in Southern and Eastern Europe, Vol. 5, pp. 489-505, 2019

M. Nikšić Radić, D. Gračan, M. Barkiđija Sotošek: AGE OF MIGRATION: A CHANCE FOR ...

\title{
AGE OF MIGRATION: A CHANCE FOR RESPONSIBLE TOURISM AND NEW TOURISM EXPERIENCE
}

\author{
Maja Nikšić Radić \\ Daniela Gračan \\ Marina Barkiđija Sotošek
}

https://doi.org/10.20867/tosee.05.36

\begin{abstract}
Purpose - Taking into account both parallel phenomena, i.e. the importance of the development of an inclusive society that will encompass migrants as equal members of the community and the importance of responsible tourism, the purpose of this research is imposed. The purpose of this research is to identify best practices which can help in the development of responsible tourism as a cornerstone of sustainable tourism development and which includes migrants in this development with a view to promote social, economic and cultural cohesion.

Methodology - The research uses a literature review of this up-to-date topic and a comparative analysis of the existing best practices in Europe. The methodology applied allowed to identify the best practices how to include migrants in the tourist activity of the destination with the aim to achieve the responsible tourism development.

Findings - Due to migration, people can contact with different cultures. Migrant-led tours may help to eradicate prejudice and people are able to travel 'at kilometer zero' which both contribute to the development of responsible tourism and to the global sustainable goals. Responsible tourism is to making the tourism spot more responsible by taking advantage of the available resources and labor. Inclusion of migrants in tourism development is a brain wave that can make the destinations more responsible as well as sustainable.

Contribution - The research addresses the important research problem of how to achieve the responsible tourism development through the migrant inclusion. The research results indicate the possibilities that migration trends and multicultural differences can play in the development of responsible tourist destinations. In addition, the foundations for further research of the subject matter have been set i.e. the authors are moving towards a theory of migration-based responsible tourism development. Lastly, they have important implications for policy makers and tourist destinations managers.
\end{abstract}

Keywords migration-led tourism, tourism-led migration, responsible tourism, sustainable tourism development, multicultural differences

\section{INTRODUCTION}

Economic integration of the world or the phenomenon of globalization occurred through international trade, migration and capital flows in 1870. Before 1870, none of these flows was large enough to justify the name of globalization (World Bank, 2002). Since then and until the 21 st century international trade played the dominant role in globalization processes and capital flows. By entering the 21st century, increasingly important becomes the role of migration. Tourism as an integral part of the migration (O'Reilly, 2003), has thus become the major leading force of the globalization era, which we live 
ToSEE - Tourism in Southern and Eastern Europe, Vol. 5, pp. 489-505, 2019

M. Nikšić Radić, D. Gračan, M. Barkiđija Sotošek: AGE OF MIGRATION: A CHANCE FOR ...

in. According to the UNWTO $(2011,2012,2015)$, the number of worldwide international tourist arrivals is expected to increase by an average 3.3\% a year from 2010 to 2030 . Over time, the rate of growth is forecast to gradually slow down, from $3.8 \%$ between 2010 and 2020 to $2.9 \%$ from 2020 to 2030 . However, the actual rate of growth between 2010 and 2015 has been over $4.5 \%$ on average (UNWTO, 2016). In absolute numbers, international tourist arrivals are forecast to increase by some 43 million a year, compared to an average increase of 28 million a year during the period 1995 to 2010 . At the projected rate of growth, international tourist arrivals worldwide will reach 1.36 billion by 2020 and 1.809 billion by the year 2030, after exceeding 1 billion for the first time in 2012. By 2030, the UN WTO (2012) suggest that $57 \%$ of international arrivals will be in emerging economy destinations (versus $30 \%$ in 1980) and $43 \%$ in advanced economy destinations (versus 70\% in 1980). Economically, tourism is estimated to be worth $9 \%$ of global GDP (including direct, indirect and induced impact). This equates to approximately US\$1.5 trillion or 6\% of world exports (30\% of services exports) in 2014 (UNWTO, 2015). Importantly, tourism is estimated to account for one in every 11 jobs once direct, indirect and induced impacts are included (UNWTO, 2015). The employment generating capacities of tourism is also becoming of increasing importance given the loss of jobs to technological change in other sectors (Hall et al, 2017).

Global Migration Indicators 2018 reported that the number of international migrants was 254 million in 2017, i.e. $3.4 \%$ of the world population (IOM, 2018). According to the World Migration Report 2018 (IOM, 2017) the number of international migrants was around 244 million in 2015. By comparison, this number was 100 million in 1990, and 84 million in 1970. The share of international migrants in the world's population thus rose from $2.3 \%$ in 1970 to $3.3 \%$ in 2015 . The largest share of migrants in $2015,72 \%$ of them, is the working age population of 20 to 64 years. Out of the total number of international migrants, $62 \%$ of their international destinations have been found in Europe and Asia, followed by North America with 22\%, Africa with 9\%, Latin America and the Caribbean with 4\%, and Oceania with 3\%. According to UN DESA (2015), the largest number of migrants originates from Asia, primarily India and China and South Asian countries (Afghanistan, Bangladesh and Pakistan). Mexico is in second place, followed by numerous European countries. Significantly, it is important to emphasize that any restriction of migration hamper further economic growth. (Goldin, 2018a). Two-thirds of US growth since 2011 is directly attributable to migration; in the UK, if the number of migrants remained constant since 1990, the economy would be at least 9 per cent smaller than it is now and in Germany, if immigration also remained constant since 1990 , the net economic loss would be $6 \%$ (Goldin, 2018b).

It is evident that in the 21st century tourists and migrants have a potential role of economic growth drivers (Rode, 2008; Un News Center, 2018). They are a trigger of multiplicative economic activity and, as Bookmann (2006) pointed out, population flows are the cause and the consequence of economic growth. The fact is that while most countries are very eager to accept tourists, migrants have quite different treatment that entails many tensions.

The time we live in is called The Age of Migration because migrations have gained increasing political significance over the past decades (Castles, De Haas, Miller, 2014). The time we live in is also the time of globalization, nonetheless it cannot be the time of 
ToSEE - Tourism in Southern and Eastern Europe, Vol. 5, pp. 489-505, 2019

M. Nikšić Radić, D. Gračan, M. Barkiđija Sotošek: AGE OF MIGRATION: A CHANCE FOR ...

ethnically pure countries, nor should it be. The idea of ethnic cleansing is also contradictory in its essence. Countries advocate for the free movement of capital, goods and services, and on the other hand, they are considering closing down the borders when it comes to immigrants (Legrain, 2007). According to Glick Schiller (2015) there is a certain amount of courage in today's time to take the position of recognizing the benefits of transnational immigration links. Based on the transnational paradigm of migration, it is necessary to recognize transnational migration as "inextricably linked to the changing conditions" of global capitalism and its accumulation processes (Basch, Glick Schiller, Szanton Blanc, 1994). Bearing in mind the issue of sustainability, the only real issue of the 21 st century, it is necessary to intensively rethink how to use migration movements in the best possible way and incorporate them into the real needs of developed countries. It should also be borne in mind that sustainability does not include just the environment, but should also be seen in the context of community, culture and economics (Yeoman et al., 2015).

The inescapable fact is that the migration is the potential of sustainable economic growth and development of developed countries facing the problems of an aging population aging and the lack of labor force. Furthermore, numerous studies have confirmed the benefits that migrant employment brings to both the country and employers (Piore, 1979; Mackenzie, Forde, 2009). During the last few decades, several countries such as Spain, Ireland, Taiwan, South Korea, India, China and Turkey have experienced mutual intercourse strengthening between migration and development (Castles, De Haas, Miller, 2014).

Returning to tourism and reflecting on its responsible and then sustainable development, the exploitation of immigration potential is an exceptional opportunity for ensuring sustainable tourism development. It is well known that the immigrant labor force helps competitiveness and growth of tourism. According to Munz et al. (2007), immigration workforce contributes to long-term growth by improving the human capital of the country and therefore its innovation, productivity and competitiveness in international markets. In addition, tourism can be a force for peace (WTTC, 2016). Given this potential, tourism has the opportunity to help refugees, asylum seekers and other migrants and to contribute to the responsible tourism development through social and cultural inclusion.

Taking into account both parallel phenomena, i.e. the importance of the development of an inclusive society that will encompass migrants as equal members of the community and the importance of responsible tourism development, the research question arises as to how to link these two issues. The purpose of this research is to identify best practices which can help in the development of responsible tourism as a cornerstone of sustainable tourism development which includes migrants in this development with a view to promote economic, cultural and social cohesion. The authors focus primarily on the European area and the problem in the form of a large number of refugees with which Europe is confronted. According to Huber et al. (2010) immigration is considered one of the major determinants of European competitiveness. The main aim of the study is to identify potential linkages between tourism and migration and to point to the potential role that inclusion of migrants and refugees in tourist activities can play in the development of responsible tourism. 
ToSEE - Tourism in Southern and Eastern Europe, Vol. 5, pp. 489-505, 2019

M. Nikšić Radić, D. Gračan, M. Barkiđija Sotošek: AGE OF MIGRATION: A CHANCE FOR ...

The following section provides some stylized facts about the connection between tourism and migration. Section 2 is dealing with the conceptualization of sustainable and responsible tourism development, while Section 3 shows the examples of immigrants' inclusion in responsible tourism development. Section 4 explores the possibility of developing a theory of migration-based responsible tourism development. As a final point, policy implications are drawn in a conclusion.

\section{STATE-OF-THE-ART: CONNECTION BETWEEN TOURISM AND MIGRATION 9}

It is possible to distinguish two types of mobility: long-term migration and short-term tourist movement (Williams and Hall, 2000). Short-term tourist movements are a complement to long-term migration; they are a form of territorial movement that does not represent a permanent change of habitual residence (Bell, Ward, 2000). Therefore, it is clear that tourism is an integral part of the migration (O'Reilly, 2003). Today we may testify to now forms of mobility such as retirement migration or mobility in search of a better lifestyle. According to Castles et al. (2014), the boundary between tourism and migration becomes unclear because some people travel as tourist in pursuit for potential migration destination. However, research directed towards tourism and migration are developed independently of each other during the second half of the 20th century (Bell, Ward, 2000). It should also be stressed that, from all population trends, tourism is attracting at least academic attention (Bookman, 2006). Therefore, it is not surprising that at the end of the 20th century and at the very beginning of the 21 st century, scientific considerations of the connection of tourism and migration in globalization conditions just began (Bauman, Z., 1998; Williams, Hall, 2002).

Concerning the impact of migration on tourism, the most important point is the significance of the Visiting Friends and Relatives hypothesis. It is about people traveling to visit their friends and relatives who have previously migrated to a foreign country (Boyne, Carswell, \& Hall, 2002). Nevertheless, the presence and growth of immigrant communities can positively influence tourism flows through several channels (Dwyer et al., 2010). For example, friends and relatives, after returning to their country, convey their experiences to other friends, which will likely affect their future travel destinations. In addition, immigrants who travel back to their homeland can promote the host country and encourage further travel. It is known that immigration enriches the cultural life of host countries and provides a broader range of spending opportunities, such as ethnic restaurants and cultural events related to immigrant communities, which in turn makes the destination more attractive for all types of tourists (Etzo, 2016). Immigration movements thus influence the enrichment of culture and the creation of a diverse society. Immigrants who are entrepreneurs in the host country often use their contacts and business knowledge in the country of origin to work and thus stimulate business travel between the two countries (Seetaram, 2012). It is possible to conclude that immigration has a positive effect on tourism demand in the host country (Dwyer et al., 1993; Oigenblick and Kirschenbaum, 2002). 
ToSEE - Tourism in Southern and Eastern Europe, Vol. 5, pp. 489-505, 2019

M. Nikšić Radić, D. Gračan, M. Barkiđija Sotošek: AGE OF MIGRATION: A CHANCE FOR

The second stream of research relates to the observation of the impact of tourism on the migration. Hall and Williams (2002) distinguish two types of tourism impact on migration: production-led migration and consumption-led migration. The linkage between production and consumption with the generation of migration flows depends on a multitude of factors pertaining to tourism development itself (Williams, Hall, 2002). Likewise, this division between production and consumption allows to avoid state-based categories and to consider migration and tourism as interrelated and overlapping (Rode, 2008). Consumption-led migration includes second-home owners (Hall, Muller, 2004) and people at retirement (Williams, Hall, 2002; Hass, Serow, 1997). Production-led migration refers to the labor and entrepreneurial potential of migration. Since tourism is very labor-intensive, countries that rely heavily on tourism as a leverage for development, depend on the influx of migrants in order to satisfied the need for labor (Bookman, 2006, Choi, Woods, Murrmann, 2000). Tourism requires a wide range of different skills that local people cannot fully satisfy (Rode, 2008). Therefore, migrants as a potential work force are an important part of tourism. Tourism thus leads to labor migration as it provides employment opportunities (Shariff, Abidin, 2017).

Globalization processes have led to an increasing complexity of the two observed phenomena (Illés, Michalkó, 2008). Additionally, globalization has led to the creation of links between the growing demand for labor in tourism and labor migration (Munz et al. 2007). It is inevitable that understanding the linkage between tourism and migration requires an interdisciplinary approach (Melegh et al., 2004). So far, neither research related to tourism nor migration has adequately investigated the interrelationship of two categories, especially with regard to ethnic groups having a new pattern of overseas travel (Zaidan, Wall, 2013)

\section{CONCEPTUALIZING SUSTAINABLE AND RESPONSIBLE TOURISM DEVELOPMENT}

Sustainability comes naturally to the Earth, but not so naturally to humankind. Progress in understanding and achieving sustainability requires integration of scientific, social, economic, and legal issues. The World Commission on Environment and Development (1987) cast the concept of sustainability in its present shape. It collated a wide range of views on ecologically sustainable development (ESD) which it set out in the so-called Brundtland Report, Our Common Future. This included both biophysical and cultural spheres and enunciated a set of principles which in the South Pacific have been adopted by many governments, including Australia, New Zealand, Fiji, the Cook Islands and others. There are four fundamental canons for the World Conservation Strategy that emerged from the World Commission on Environment and Development as follows:

- Ecological sustainability. Development must be compatible with the maintenance of ecological processes, biological diversity and biological resources.

- Economic sustainability. Development must be economically efficient and equitable within and between generations.

- Social sustainability. Development must be designed to increase people's control over their lives and maintain and strengthen community identity.

- Cultural sustainability. Development must be compatible with the culture and the values of the people affected by it. 
ToSEE - Tourism in Southern and Eastern Europe, Vol. 5, pp. 489-505, 2019

M. Nikšić Radić, D. Gračan, M. Barkiđija Sotošek: AGE OF MIGRATION: A CHANCE FOR ...

The term sustainability is derived from the Latin word sustinere, which in turn is made up of sub - meaning: under - and tenere - meaning: hold. In English, to sustain can mean to maintain, to support, or to endure. By adding 'ability' to 'sustain', the term sustainability then logically refers to the ability to support, to maintain or to endure. In other words, taken literally, something sustainable is something that endures for a long time - something that does not wear out quickly. However, over the years we have come to interpret the term sustainability differently (Smit and Melissen, 2018: 172).

Mainstream environmental practices first emerged in the 1980s, when recycling became a household word for the first time. In 1987, the United Nations took the bold step of writing Our Common Future, a new theory for business and society to progress without harming the planet. This important text created the theory of sustainable development, or "development that meets the needs of the present without compromising the ability of future generations to meet their own needs" (UNWCED, 1987: ch. 2).

Human sustainability, as Martin and Schouten (2014: 11) define it, is the opportunity for all people to maintain fulfilling, productive lives while preserving or replenishing the natural and economic systems that make their well-being possible. According YanezArancibia et al (2013: 3) sustainability is defined as 'meeting human needs in a socially and economically fair manner without depriving ecosystems of their health'; most of the words in its definition are normative and carry some value. Depending on how critical normative terms are defined, sustainability could mean anything from 'exploit as much as desired without infringing on the future ability to exploit as much as desired' to 'exploit as little as necessary to maintain a meaningful life'. Authors suggest that there are different steps towards sustainability, starting with the problem of both global change and human impacts that are putting in jeopardy both the environment and the sustainability of resource exploitation. If social and economic development ignores the ecological dimension, or there is a lack of attention to environmental values, ethics, laws, or policy dimensions of sustainability, the progress towards sustainable development would be utopian. DeBlanc Goldblatt (2012: 4) defines sustainability like ethical behavior with a long-term perspective that covers more topics than just environmentalism. Sustainability means thinking not just about tomorrow, or next year, but about 100 or 1,000 years from now, and it remains a critical principle for modem business.

The tourism sector has been a relative latecomer to the development debate and to its responsibilities and role in advancing sustainable development. In the immediate postWorld War 2 rush to develop, tourism was initially ignored in the national development plans of most Third World countries. In other parts of the Third World, such as the Caribbean, the importance of tourism had been recognized earlier and led to such descriptions by economic advocates as "tourism, passport to development" (challenged by de Kadt in his 1979 book of that name according Sofield, 2003: 6).

In the past two decades, tourism has begun to find general recognition as an economic sector that can contribute to "development". Virtually all countries around the globe have now embraced tourism, with greater or lesser enthusiasm. The tourism industry, with its reliance on recreational air travel, is one of the world's large gas consumers and polluters. Tourist activity can also degrade both the ecological and social life of a native population. 
ToSEE - Tourism in Southern and Eastern Europe, Vol. 5, pp. 489-505, 2019

M. Nikšić Radić, D. Gračan, M. Barkiđija Sotošek: AGE OF MIGRATION: A CHANCE FOR

Bearing in mind that tourism is world's prevalent industry the question is how does it reflect the environment and sustainability? A UNWTO, UNEP and WMO (2008) examination of the tourism sector contribution to global $\mathrm{C} 02$ emissions estimated that in 2005, tourism transport, accommodation and activities contributed approximately $5 \%$ to global anthropogenic emissions of $\mathrm{C} 02$. Most $\mathrm{C} 02$ emissions are caused by transport, with aviation accounting for $40 \%$ of tourism's overall carbon footprint, followed by car transport $(32 \%)$ and accommodation $(21 \%)$.

Taking into account the financial impact of tourism, but also its environmental impact and its possibility of maintenance sustainability, responsible leaders will always try to find a compromise between economic, ecological, social and cultural sustainability and in their long-term business plans.

Responsible tourism is tourism that in practice enforces the principles of sustainability (Stanford, 2006). In accordance with the Declaration of Cape Towne, responsible tourism involves the creation of respect and building of local pride, generating greater economic benefits especially for the local population and their involvement in decisionmaking, encouraging significant links between the guests and the local population and respecting the cultural and natural diversity (Spenceley, 2012). Responsible tourism requires operators, hoteliers, governments, local people and tourists to take responsibility and take measures to make tourism more sustainable (Scheyvens, Biddulph, 2017). According to Husbands and Harrison (1996), responsible tourism is a way of doing tourism, what is being done by the tourist to achieve responsible tourism and by others to enable the tourist to participate in responsible tourism.

Tourism has grown fast, and at the same time, it has also found many problems common to other development strategies facing "outward", such as: excessive external dependence, the creation of enclaves, reinforcement of socioeconomic and spatial inequalities, environmental destruction and increase of cultural alienation (Brohman, 1996 cited in Tomio Dreher et. al., 20213: 285). In order to prevent those "outward" facts, responsible actions should be taken into consideration as the idea of guiding. In that context, responsible tourism should make careful use of environmental resources to ensure the maintenance of essential ecological processes and the conservation of natural heritage and biodiversity. Furthermore, responsible tourism should respect the sociocultural authenticity of host communities, preserving their typical building structures, their cultural heritage and traditional values, and cooperating for better intercultural understanding. This form of tourism should support economically viable and long-lasting operations with economic benefits appropriately distributed to all stakeholders; and promote stable employment and the possibility of benefits and social services for hosting communities, contributing to poverty reduction (Musarò, 2014: 102).

Authors of this article emphasize a guideline "Open your mind to other cultures and traditions"(WCTE and UNWTO, 2005) as a crucial manner for changing local people opinion on, unfortunately, the usual viewing immigrants as threat for locals. By opening our mind to other cultures and embracing immigrants traditions can led to a good practice by implementing responsible tourism and including immigrants into a tourism sector explained in the next chapter. 
ToSEE - Tourism in Southern and Eastern Europe, Vol. 5, pp. 489-505, 2019

M. Nikšić Radić, D. Gračan, M. Barkiđija Sotošek: AGE OF MIGRATION: A CHANCE FOR ...

\section{INCLUSION OF IMMIGRANTS IS RESPONSIBLE TOURISM DEVELOPMENT IN PRACTICE}

Immigration has a valuable role to play in strengthening the EU's competitiveness, addressing current and future demographic challenges and filling labor shortages. The key to maximizing the benefits of immigration is the successful integration of migrants into their host societies.

Generally, people believe that immigrants are poorer, more dependent on welfare, and more numerous than they really are (Migration data portal, 2019). Public opinion on migration may also influence the degree to which a migrant integrates into their receiving community (Merelli, 2018). European residents appear to be, on average, the most negative globally towards immigration, with the majority believing immigration levels should be decreased. People's views about their personal and their countries' economic situations may be the strongest predictors of their views of immigration. Those who perceive economic situations as poor or worsening are more likely to favor lower immigration levels into their countries. The reverse is also true: those who perceive their individual or their countries' economic situations as good or improving are more likely to want to see higher levels of immigration (IOM, 2015: 1).

Tourism has the opportunity to play a crucial role in this area. Nevertheless, according to Smith (2017), tourism is ,an industry based on providing a welcome for foreigners”. Travindy, a website launched by Berlin-based tourism consultant, published " 15 Ways Tourism Can Help Refugees". This document gathers together examples of various tourism companies around the world acting proactively to help support refugees and suggests ways everyone in the industry - from hotels and tour companies, to attractions, airlines and destinations can get involved (Smith and Galewska, 2015).

The following table summarizes the possible ways of conducting responsible tourism on the principles of migrants' inclusion.

Table 1: 15 ideas on how to develop responsible tourism by involving migrants'

\begin{tabular}{|c|l|}
\hline Accommodation & $\begin{array}{l}\text { Billionaire Petter Stordalen owns Scandinavia's largest hotel chain, Nordic } \\
\text { Choice Hotels. He offered 5,000 free nights in his hotel chain to refugees. } \\
\text { The Magda hotel in Vienna has two suites set aside for refugee children } \\
\text { under 18 without parents. And VVF Villages in France has made } 20 \text { of } \\
\text { their holiday villages available for refugee families to live in. Whether } \\
\text { done out of generosity, or as a way of filling the rooms during quiet } \\
\text { periods, hotels are often in a position to provide short term } \\
\text { accommodation, at a cost many refugees could afford. }\end{array}$ \\
\hline Meeting spaces & $\begin{array}{l}\text { One of the biggest issues affecting migrants to new countries is loneliness. } \\
\text { Hotels could offer up their empty conference rooms, banqueting suites and } \\
\text { other public spaces to refugee and migrant support groups. }\end{array}$ \\
\hline
\end{tabular}


ToSEE - Tourism in Southern and Eastern Europe, Vol. 5, pp. 489-505, 2019

M. Nikšić Radić, D. Gračan, M. Barkiđija Sotošek: AGE OF MIGRATION: A CHANCE FOR ...

\begin{tabular}{|c|c|}
\hline $\begin{array}{c}\text { Invite round to } \\
\text { watch the } \\
\text { football }\end{array}$ & $\begin{array}{l}\text { All across the world, the first question a tourist is often asked is which } \\
\text { Premiership or European football side they support, prompting a } \\
\text { conversation of shared thoughts and passions. Whether screening a big } \\
\text { game in the lobby bar, or setting up a dedicated room, simply inviting } \\
\text { refugees to come and support their team offers a welcome and enables } \\
\text { them to make connections with locals who share their love of the game. If } \\
\text { a hotel has the outside space, they could invite people to come and play a } \\
\text { game, or maybe encourage the setting up of a local refugees' football team, } \\
\text { and then challenge them to a game against the hotel's team. }\end{array}$ \\
\hline Employment & $\begin{array}{l}\text { In Europe, countries are seeing ageing populations and lowering birth } \\
\text { rates. About one-third of Germany, Italy and Spain will be over } 65 \text { in } 2050 \text {. } \\
\text { Immigrants can fill that gap. In Germany, website Workeer.de enables } \\
\text { employers to find relevantly skilled refugees. However, responsible } \\
\text { tourism companies can't just see this as an excuse to cut wages - the abuse } \\
\text { of low-paid migrant workers is a blight on the hotel sector that also needs } \\
\text { to be fixed. }\end{array}$ \\
\hline Chefs & $\begin{array}{l}\text { At the Mazi Mas pop up restaurant in South London, immigrant and } \\
\text { refugee women from all over the world prepare local dishes from their } \\
\text { home countries. The menu changes every three days and is put on the } \\
\text { restaurant's website in advance. Even if a hotel isn't looking for a full time } \\
\text { chef it could host a themed evening based around restaurant concepts like } \\
\text { this. There's also bound to be musicians and other performers among local } \\
\text { refugee communities as well. }\end{array}$ \\
\hline $\begin{array}{l}\text { Help guests } \\
\text { discover new } \\
\text { communities }\end{array}$ & $\begin{array}{l}\text { In cities like London, much of the most vibrant food and cultural } \\
\text { happenings can be found in the migrant communities. But would a tourist } \\
\text { from abroad know of the Vietnamese communities in Hackney, or the } \\
\text { Bangladeshis of Brick Lane? } \\
\text { Do most visitors to Paris know where to find Petit Mali? Hotels are } \\
\text { knowledge hubs for their communities, and the information that they } \\
\text { provide defines a visitor's experience. }\end{array}$ \\
\hline $\begin{array}{c}\text { Create refugee } \\
\text { led tours }\end{array}$ & $\begin{array}{l}\text { Over the last } 24 \text { months, Migrantour has been creating a European network } \\
\text { promoting guided walks led by citizens from migrant backgrounds, } \\
\text { designed to promote intercultural diversity and to provide an added source } \\
\text { of income for disadvantaged migrants. The walks are guided by migrants } \\
\text { from old and new generations, with the aim of showing tourists, students } \\
\text { and locals their neighbourhoods as they perceive and experience them. So } \\
\text { far they have taken place in nine European cities (Turin, Milan, Genoa, } \\
\text { Florence, Rome, Marseille, Paris, Valencia and Lisbon), and over } 11,000 \\
\text { people have taken part in these walks. Plans are being developed to spread } \\
\text { the concept much more widely across Europe. } \\
\text { Besides the project "MygranTour", there are two similar projects with the } \\
\text { wary similar purpose. The project "Our invisibile cities. Meetings and new } \\
\text { narration of the world within city" is a global citizenship education } \\
\text { initiative that aims to tackle improper and discriminative representations } \\
\text { of migration and cultural diversity. The initiative, launched in March } 2018 \\
\text { in } 10 \text { Italian cities intends to contribute to the diffusion of a new narration } \\
\text { based on the equal dignity of the Other and on the enhancement of the } \\
\text { contribution of the ancient and current migrations to our society. } \\
\text { The European Migrantour network is also supported by the project "New } \\
\text { Roots - Migrantour intercultural walks building bridges for newcomers } \\
\text { active participation". Active in } 10 \text { cities of } 4 \text { different European countries, } \\
\text { this initiative is built on the basis of the results achieved by the Migrantour } \\
\text { project. }\end{array}$ \\
\hline
\end{tabular}


ToSEE - Tourism in Southern and Eastern Europe, Vol. 5, pp. 489-505, 2019

M. Nikšić Radić, D. Gračan, M. Barkiđija Sotošek: AGE OF MIGRATION: A CHANCE FOR ...

\begin{tabular}{|c|c|}
\hline $\begin{array}{c}\text { Invite refugees } \\
\text { on tours }\end{array}$ & $\begin{array}{l}\text { Not every tour is full of paying guests. And even if it is, tour companies } \\
\text { could create a policy such as offering one free space to a recently arrived } \\
\text { migrant for every } 10 \text { paying guests. } \\
\text { Not only would a walking tour of the local area provide insights and } \\
\text { connections to their new neighbourhood, it also opens up a space for } \\
\text { refugees and tourists to talk, and exchange their perceptions of the city they } \\
\text { are both discovering. }\end{array}$ \\
\hline $\begin{array}{c}\text { Create } \\
\text { Diaspora- } \\
\text { focussed tours }\end{array}$ & $\begin{array}{l}\text { Whether designed to be run by refugees as in the case of Migrantour; to } \\
\text { offer opportunities for refugees to discover their new city; or simply as } \\
\text { ways to offer new ways of seeing a city to interested tourists, the ever } \\
\text { increasing diversity of the world's modern cities makes them ideal for tours } \\
\text { which focus on the experience of refugees, migrants and other diaspora } \\
\text { communities. } \\
\text { In the Hague, for example, City Mondial is a multicultural tourist } \\
\text { information centre providing walking tours to diverse neighbourhoods of } \\
\text { the city, such as the Schilderswijk, Transvaal and Stationsbuurt - where } \\
\text { more than } 80 \% \text { of the population are of non-Dutch ethnic background. } \\
\text { Tourists get to experience Turkish mosques, Hindu temples and the local } \\
\text { multicultural markets located within the Hague. } \\
\text { Neighbourhoods featured as part of City Mondial tour offer now receive } \\
\text { over } 200,000 \text { visitors a year and seen a } 60 \% \text { increase in the number of } \\
\text { businesses in the area. }\end{array}$ \\
\hline $\begin{array}{l}\text { Showcase the } \\
\text { mix of cultures } \\
\text { in your } \\
\text { community }\end{array}$ & $\begin{array}{l}\text { At every level, from the hotel to the destination, there is a need to } \\
\text { differentiate what you offer to make yourselves attractive to visitors. The } \\
\text { celebration of the contributions of migrants to local culture is an essential } \\
\text { part of what makes many cities so desirable to visit. } \\
\text { Rather than the negative message that migrants are supposed to 'adopt the } \\
\text { ways of their new host culture, it is far more productive and positive to } \\
\text { foster ways of championing the range of cultures now living in close } \\
\text { proximity. } \\
\text { Every year, Refugee Week sees hundreds of events across a countrywide- } \\
\text { wide programme of arts, cultural and educational events and activities that } \\
\text { celebrate the contribution of refugees to the UK. }\end{array}$ \\
\hline $\begin{array}{l}\text { Rethink our } \\
\text { museums as } \\
\text { integration } \\
\quad \text { hubs }\end{array}$ & $\begin{array}{l}\text { In } 2010 \text {, London's Victoria and Albert Museum marked Refugee Week by } \\
\text { enabling visitors to see its collection from the perspective of a refugee, it } \\
\text { offered a series of unique tours of its galleries guided by refugees from } \\
\text { Rwanda, Burma, Iraq, Somalia, Sudan, and Uganda. The guides not only } \\
\text { presented the collections as they saw them, but used the tours as } \\
\text { springboards for their own personal stories and experiences. }\end{array}$ \\
\hline $\begin{array}{l}\text { Set up refugee } \\
\text { dining clubs }\end{array}$ & $\begin{array}{l}\text { The success of schemes like Eat With (which is a community shared dining } \\
\text { experiences in peoples homes) could easily embrace refugee and migrant } \\
\text { communities. Whether inviting refugees as guests to dinners in your own } \\
\text { home, or developing ways that they can be the hosts, the creation of refugee } \\
\text { dining clubs offers potential to tap into the sense of welcome that sharing } \\
\text { food provides. }\end{array}$ \\
\hline $\begin{array}{l}\text { Repurpose what } \\
\text { you can }\end{array}$ & $\begin{array}{l}\text { Bed sheets. Linen. Food. Glassware. Hotels go through a lot of resources, } \\
\text { much of which is discarded long before its life is over, simply because it } \\
\text { might not look new enough to guests. Connect with refugee support groups } \\
\text { in your area and see what they need. And tell guests that if they bring over } \\
\text { items, you will ensure they get delivered where they are most needed. }\end{array}$ \\
\hline
\end{tabular}


ToSEE - Tourism in Southern and Eastern Europe, Vol. 5, pp. 489-505, 2019

M. Nikšić Radić, D. Gračan, M. Barkiđija Sotošek: AGE OF MIGRATION: A CHANCE FOR ...

\begin{tabular}{|c|l|}
\hline $\begin{array}{c}\text { Raise luggage } \\
\text { allowance for } \\
\text { bringing } \\
\text { supplies }\end{array}$ & $\begin{array}{l}\text { Certain airlines and travel companies have offered travellers up to 20kg } \\
\text { extra luggage allowance if they use it to bring requested supplies to places } \\
\text { such as the Greek islands of Kos and Lesbos, which as well as being } \\
\text { popular tourist destinations are also often the first place refugees from } \\
\text { Syria arrive in Europe. These airlines should be congratulated, and others } \\
\text { encouraged to do the same. }\end{array}$ \\
\hline $\begin{array}{c}\text { Help refugees } \\
\text { fly in }\end{array}$ & $\begin{array}{l}\text { Refugeeair is a campaign in Sweden that has teamed up with entrepreneurs, } \\
\text { business people and leading professionals, and is working closely with } \\
\text { carriers and NGOs to help make safe air routes to Europe possible. The } \\
\text { intention is to fly in refugees (who will then be met and have their } \\
\text { application processed at the border) rather than them risk perilous boat } \\
\text { crossings. The hashtag is \#LetThemFly. }\end{array}$ \\
\hline
\end{tabular}

Source: authors according Smith, J. and Galewska, A. (2015) 15 ideas for how tourism can support refugees. Retrieved from:

https://www.travindy.com/wp-content/uploads/2015/09/How-Tourism-can-support-refugees.pdf

These free briefings seek to stimulate thought and action into urgent global issues the travel industry can help address. They combine examples of creative responses already being employed by people in tourism, along with suggestions for what more might be done.

\section{POTENTIAL OF MIGRATION-BASED RESPONSIBLE TOURISM DEVELOPMENT}

Migration has always been in the human nature that strives for greater prosperity, and globalization conditions that govern the world are just an accelerator of that aspiration. Human nature is also a striving for progress that has called into question the economic, ecological, sociological and cultural sustainability of further development of the human species. All migration-related forecasts, including tourism, indicate that there are continuous growth rates ahead of them.

Tourism as the current generator of economic growth can only preserve its development if the principles of sustainable development are maintained. This means that their business must be based on responsible tourist development, which implies the implementation of the sustainability principles. Given its economic power, it is not surprising that it has a noteworthy role in the achievement of the 2030 Agenda for Sustainable Development (Nikšić Radić, 2018). Once again, it should also be mentioned that migration has the potential to be a generator of economic growth.

It is possible to conclude, from the literature review that deals with the relationship between tourism and migration that the mutual linkage of these two phenomena will only grow in the decades to come. An overview of the interconnectedness of tourism and migration gives the figure below. 
ToSEE - Tourism in Southern and Eastern Europe, Vol. 5, pp. 489-505, 2019

M. Nikšić Radić, D. Gračan, M. Barkiđija Sotošek: AGE OF MIGRATION: A CHANCE FOR ...

Figure 1: Interconnection between tourism and migration and a chance for responsible tourism development

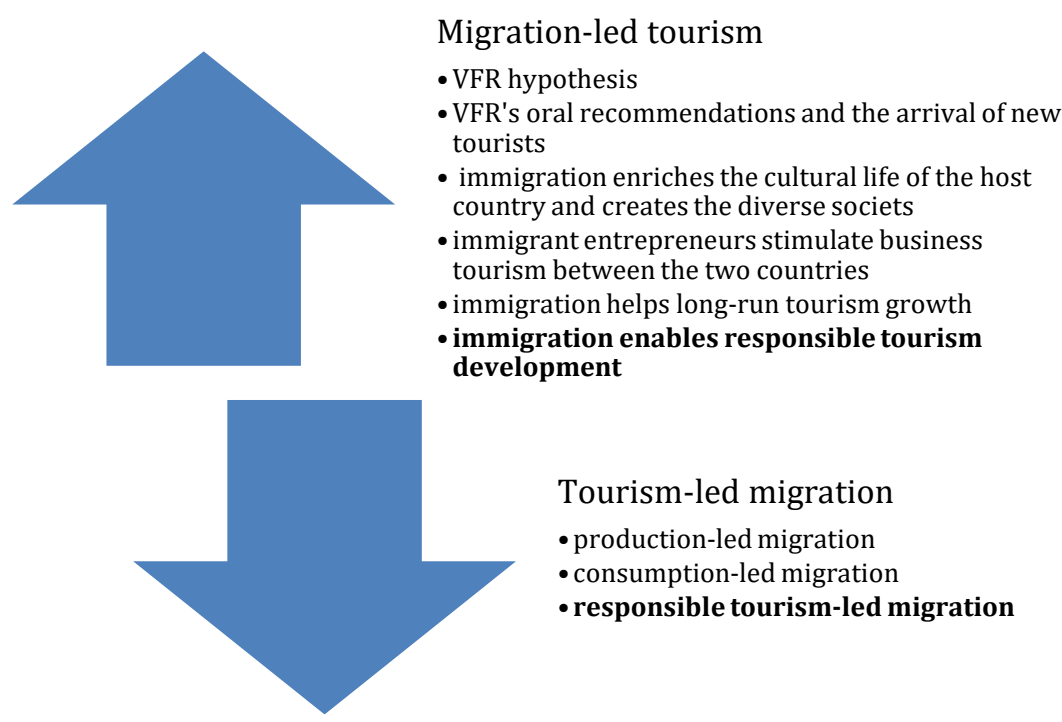

Source: Authors according to Williams, Hall, 2002; Seetaram, 2012; Munz et al., 2007; Dwyer et al., 2010; Boyne, Carswell, \& Hall, 2002; Hall, Muller, 2004; Hass, Serow, 1997; Shariff, Abidin, 2017

Migration-led tourism hypothesis argues that migration can affect the development of tourism. Migrants visit relatives and friends, then the same visitors convey knowledge of the host country and thus encourage the arrival of new tourists, migrants significantly enrich the host country's culture, immigrant entrepreneurs influence the development of tourism activities in the host country and ultimately migrants influence the further tourism growth. Furthermore, taking into account examples of best practice from previous analysis, immigration can contribute to the development of responsible tourism by providing a sustainable travel experience and by discovering the authentic cultural heritage of migrants' home countries.

Tourism-led migration hypothesis argues that tourism can affect migration through the supply side and through the demand side. In other words, on the one hand, tourism attracts second-home owners and people in retirement and on the other hand, tourism and hospitality industry is attractive to migrants because it is relatively easily accessible given the necessary linguistic and other skills (Janta, et al., 2011). Likewise, responsible tourism can influence the increased inclusion of refugees, asylum seekers and other migrants. Proof findings are positive practices presented in the previous section.

Migrants often lead to tensions in the community they enter, especially if they do not integrate into the society of the host country and challenge social standards (Rogers et al., 2009). Immigrants, if they are colored, often observe anger and distrust in the communities they enter (Kozak, Kozak, 2015). Despite the continuing demand for their services, due to the ethnic and racial diversity they bring with them, they are followed by a growing aversion of the domicile population (Espenshade, Hempstead, 1996). 
ToSEE - Tourism in Southern and Eastern Europe, Vol. 5, pp. 489-505, 2019

M. Nikšić Radić, D. Gračan, M. Barkiđija Sotošek: AGE OF MIGRATION: A CHANCE FOR ...

Migration-based responsible tourism development has the opportunity to contribute to global cultural, economic and sociological inclusion, and thus to the global goals of sustainable development. In addition, the inclusion of migrants in tourist activities helps further development of responsible tourism by offering tourists new, sustainable, tourist products. Such a positive example is certainly above-mentioned project Mygrantour promoting the slogan "tourism at zero kilometers or traveling the world in just one city square". It is a tourist product that indicates a pioneering example of responsible tourism development, which is based on the inclusion of migrants.

\section{CONCLUSION}

The continuous upward trend in the number of tourist arrivals at global level has led to the development of a concept of responsible tourism that was defined in Cape Town in 2002 and, over time, its importance becomes more and more important. Its main goal is to "make better places for people to live in and better places for people to visit" (Cape Town Declaration on Responsible Tourism in Destinations, 2002). In parallel, thanks to the process of global integration, with an increase in the movement of people from the tourism initiative that imply some kind of pleasure, there are also large migratory movements of people who are usually motivated by a quest for a better life.

Migration movements, including tourism, also affect the creation of national policies. Though the last decade has seen the rise of extremist and exclusive political ideas, it is necessary to bear in mind the established pattern of development that migration retreats. According to Hernandez (2018), immigrants who come to a certain place are not isolated from their homes, communicate with each other, form clusters, bring new ideas, skills and money. After a while, the companies that originate from their countries, taking capital investment and ultimately employ migrants and locals follow them.

Looking at the current practice examples it is possible to conclude that the inclusion of migrants as the active participants of the society is an opportunity for the development of responsible tourism. Because of immigration, people can meet different cultures. It is something they would not have been able to do in a world where everyone stays where they live. Immigrants bring in new dynamics when they move to new country. Even when there is no possibility to travel outside the country, thanks to project like Mygrantour, people can still learn a little about other countries or continents through the immigrants who live outside their home city, about their clothing, language or their culture.

Experiencing new cultures, other nationality customs, socializing with locals who are not originally from the same country, is a privilege enjoyed by residents whose neighbours came in seek of a better life opportunity. In this way, people can experience sustainable travel and in the same time create meaningful and immersive travel experiences aimed at discovering the authentic cultural heritage of a migrants home countries.

Inclusion of migrants in tourism development is a brain wave, which can make the destinations more responsible as well as sustainable. The research addresses the important research problem of how to achieve the responsible tourism development 
ToSEE - Tourism in Southern and Eastern Europe, Vol. 5, pp. 489-505, 2019

M. Nikšić Radić, D. Gračan, M. Barkiđija Sotošek: AGE OF MIGRATION: A CHANCE FOR ...

through the migrant inclusion. On the one hand, migrants can enrich an existing tourist offer, and on the other hand, the inclusion of migrants into tourism activities contributes to their inclusion in society. This is a good way to foster cross-cultural understanding and highlight how ethnic diversity enriches communities. The research results indicate the possibilities that migration trends and multicultural differences can play in the development of responsible tourist destinations.

This research sets the foundation for further research of the subject matter i.e. the authors are moving towards a theory of migration-based responsible tourism development. Lastly, they have important implications for policy makers and tourist destinations managers.

To end with, as Smith (2017) said, "reinvigorating the role of hospitality will therefore be central to defining our future too".

\section{ACKNOWLEDGEMENTS}

This work was supported by the University of Rijeka under Grant ZP UNIRI 8/18.

\section{REFERENCES}

Bauman, Z. (1998), Globalization: The Human Consequences, Columbia University Press, New York.

Basch, L., Glick Schiller, N. and Szanton Blanc, C. (1994), Nations Unbound: Transnational Projects, Postcolonial Predicaments, and Deterritorialized Nation-States, Amsterdam: Gordon and Breach.

Bell, M., Ward, G. (2000), “Comparing temporary mobility with permanent migration”, Tourism Geographies, Vol. 2, No. 1, pp. 87-107.

Bookman, Z.M. (2006), Tourists, Migrants \& Refugees: Population Movements in Third World Development, Lynne Rienner Pub, Boulder, CO.

Boyne S., Carswell F., Hall D. (2002), "Reconceptualising VFR Tourism: Friends, Relatives and Migration in a Domestic Context", in Hall C.M., Williams A.M. (eds), Tourism and Migration: New Relationship between Production and Consumption, Kluwer Academic Publishers, Dordrecht.

Brohman, J. (1996), "New directions in tourism for third world development", Annals of Tourism Research, Vol. 23, No. 1, pp. 48-70

Castles, S., De Haas, H., Miller, M.J. (2014), The Age of Migration, Palgrave Macmillan.

Choi, J.G., Woods, R.H., Murrmann, S.K. (2000), "International labor markets and the migration of labor forces as an alternative solution for labor shortages in the hospitality industry", International Journal of Contemporary Hospitality Management, Vol. 12, No. 1, pp. 61-67.

DeBlanc Goldblatt, S. (2012), The complete guide to greener meetings and events, John Wiley \& Sons, Inc. New Jersey.

Dwyer, L., Burnley, I., Murphy, P., Forsyth, P. (1993), “ourism - Immigration interrelations, Report Prepared for Bureau of Immigration Research.

Dwyer, L., Forsyth, P., King, B., Seetaram, N. (2010), Migration-related determinants of Australian inbound and outbound tourism flows, STCRC Centre for Economics and Policy, Sustainable Tourism Pty Ltd

Espenshade, T.J., Hempstead, K. (1996), "Contemporary American Attitudes toward U.S. Immigration", International Migration Review, Vol. 30, No. 2, pp. 535-570. https://doi.org/10.1177/019791839603000207

Etzo, I. (2016), The impact of migration on tourism demand: evidence from Japan, MPRA Paper 72457, University Library of Munich, Germany.

Glick Schiller, N. (2015), "Explanatory frameworks in transnational migration studies: the missing multi-scalar global perspective", Ethnic and Racial Studies, Vol. 38, No. 13, pp. 2275-2282. doi:10.1080/01419870.2015.1058503 
ToSEE - Tourism in Southern and Eastern Europe, Vol. 5, pp. 489-505, 2019

M. Nikšić Radić, D. Gračan, M. Barkiđija Sotošek: AGE OF MIGRATION: A CHANCE FOR ...

Goldin, I. (2018a), Immigration is vital to boost economic growth, Financial Times [online] viewed 12 January 2019, https://www.ft.com/content/f1ca7b14-b1d6-11e8-87e0-d84e0d934341

Goldin, I. (2018b), Migration and the Economy: Economic Realities, Social Impacts and Political Choices, Citi GPS: Global Perspectives \& Solutions [online] viewed 21 January 2019 https://www.oxfordmartin.ox.ac.uk/downloads/reports/2018_OMS_Citi_Migration_GPS.pdf

Haas, W.H., III, Serow, WJ. (1997), "Retirement migration decision making: Life course mobility, sequencing of events, social ties and alternatives", Journal of the Community Development Society, Vol. 28, No. 1, pp. 116-30.

Hall, C.M., Le-Klaehn, D.-T., Ram, Y. (2017), Tourism, public transport and sustainable mobility, Channel View Publications, Bristol.

Hall, M., Müller, M., (2004), "Introduction: Second Homes, Curse or Blessing? Revisited”, in Hall, M., Müller, M. (eds) Tourism, Mobility and Second Homes: between Elite Landscapes and Common Ground, Channel View Publications, Clevedon.

Hernandez, E. (2018), Where Immigrants Go, Economic Growth Follows, [online] viewed 17 January 2019, http://knowledge.wharton.upenn.edu/article/economic-debate-immigration-reform/

Huber, P., Landesmann, M., Robinson, C., \& Stehrer, R. (2010), "Migrants' skills and productivity: A European perspective”, National Institute Economic Review, 213, R20-R34. https://doi.org/10.1177/0027950113803222

Husbands, W., Harrison, L.C. (1996), Practicing responsible tourism: Understanding tourism today to prepare for tomorrow, John Wiley, New York.

Illés, S., Michalkó, G. (2008), "Relationships between International Tourism and Migration in Hungary: Tourism Flows and Foreign Property Ownership", Tourism Geographies, Vol. 10, No. 1, pp. 98 118. doi:10.1080/1461668070182527

International Organization for Migration IOM (2017), World Migration Report 2018, [online] viewed 10 January 2019, https://doi.org/10.18356/f45862f3-en

International Organization for Migration IOM (2018), Global Migration Indicators: Global Migration Data Analysis Centre (GMDAC), [online] viewed 08 January 2019, https://publications.iom.int/system/files/pdf/global_migration_indicators_2018.pdf

International Organization for Migration (2015), How the world views migration, online] viewed 15 February 2019, https://publications.iom.int/system/files/how_the_world_gallup.pdf

Janta, H., Ladkin, A., Brown, L., Lugosi, P. (2011), "Migrant relationships and tourism empoyment", Annals of Tourism Research, Vol. 38, No. 4, pp. 1322-1343.

Kozak, M., Kozak, N. (2015), Tourism Economics: A Practical Perspective, Cambridge Scholars Publishing, UK.

Legrain, P. (2007), Immigrants - Your Country Needs Them, Princeton University Press, Princeton.

Mackenzie, R., Forde, C. (2009), "The rhetoric of the 'good worker' versus the realities of employers' use and the experiences of migrant workers", Work, Employment and Society, Vol. 23, No. 1, pp. 142-159.

Martin, D., Schouten, J. (2014), Sustainable marketing, Pearson cop., Harlow.

Melegh, A., Kondratina, E., Salmenhaare, P., Hablicsek, L., Hegyesi, A. (2004), Globalisation, Ethnicity and Migration. The Comparison of Finland, Hungary and Russia, [online] viewed 21 January 2019 , http://www.demografia.hu/en/publicationsonline/index.php/demografiaenglishedition/article/view File/258/588

Merelli, A. (2018), What do Americans think about immigration? World Economic Forum. [online] viewed 17 January 2019, https://www.weforum.org/agenda/2018/07/what-americans-totally-misunderstandabout-immigration-in-one-chart

Migration data portal: The bigger picture (2019), Public opinion on migration. [online] viewed 21 January 2019, from: https://migrationdataportal.org/themes/public-opinion-migration

Munz, R., Straubhaar, T., Vadean, F., Vadean, N. (2007), What are the migrants' contributions to employment and growth? A European approach, HWWI Policy Paper 3-3, Affiliation: Hamburg Institute of International Economics.

Musarò, P. (2014), "Responsible tourism as an agent of sustainable and socially-conscious development", Revista de Pensament $i$ Anàlisi, Vol. 0, Iss. 15, pp. 93-107 [online] viewed 12 January 2019, https://pdfs.semanticscholar.org/b461/ba67c8a5a05046c6005825f1d0b84e98404c.pdf

Nikšić Radić, M. (2018), "Terrorism as a Determinant of Attracting FDI in Tourism: Panel Analysis", Sustainability, Vol. 10, pp. 4553, doi:10.3390/su10124553

Oigenblick, L., Kirschenbaum, A. (2002), "Tourism and immigration: Comparing alternative approaches", Annals of Tourism Research, Vol. 29, No. 4, pp. 1086-1100.

O'Reilly, K. (2003), "When is a tourist? The Articulation of Tourism and Migration in Spain's Costa del Sol", Tourist Studies, Vol. 3, No. 3, pp. 301-317.

Piore, M.J. (1979), Birds of passage: Migrant labor and industrial societies, Cambridge University Press, UK. 
ToSEE - Tourism in Southern and Eastern Europe, Vol. 5, pp. 489-505, 2019

M. Nikšić Radić, D. Gračan, M. Barkiđija Sotošek: AGE OF MIGRATION: A CHANCE FOR ...

Rode, N.C.W. (2008), The tourism - migration nexus: towards a theory of global human mobility, Ryerson University, Toronto.

Rogers, A., Anderson, B., Clark, N. (2009), Recession, Vulnerable Workers and Immigration, A Report Prepared for Centre for Migration, Policy and Society. COMPAS.

Scheyvens, R., Biddulph, R. (2017), "Inclusive tourism development”, Tourism Geographies, pp. 1-21. doi:10.1080/14616688.2017.1381985

Seetaram, N. (2012), "Immigration and international inbound tourism: Empirical evidence from Australia", Tourism Management, Vol. 33, No. 6, pp. 1535-1543.

Shariff, N.M., Abidin, A.Z. (2017), "Developing International Migrant Labors Pattern: The Case of Tourism and Hospitality Industry", International Review of Management and Marketing, Vol. 7, No. 1, pp 423-427.

Smit, B., Melissen, F. (2018), Sustainable customer experience design : co-creating experiences in events, tourism and hospitality, Routledge, New York.

Smith, J. (2017), How tourism is providing hospitality and support to refugees and asylum seekers. [online] viewed 03 January 2019, https://news.wtm.com/how-tourism-is-providing-hospitality-andsupport-to-refugees-and-asylum-seekers/

Sofield, H.B.T. (2003), Empowerment For Sustainable Tourism Development, Elsevier, UK.

Spenceley, A. (Ed.) (2012), Responsible tourism: Critical issues for conservation and development, Earthscan, London.

Stanford, D. (2006), Responsible tourism, responsible tourists: What makes a responsible tourist in New Zealand? Doctoral thesis, Victoria University of Wellington.

The World Bank (2002), Globalization, growth, and poverty : building an inclusive world economy (English), [online] viewed 21 January 2019 , http://documents.worldbank.org/curated/en/954071468778196576/Globalization-growth-andpoverty-building-an-inclusive-world-economy

Tomio Dreher, M., Machado Carrion, R. da S., Kuczmynda da Silveira, A.P. (2013), "Working in the tourism sector: social inclusion and prejudices", Cuadernos de Turismo, No. 32, pp. 281-294

UN DESA (2015) Datasets for the 2015, [online] viewed 21 January 2019, www.un.org/en/development/desa/population/migration/data/estimates2/estimates 15. shtml.

United Nations World Tourism Organization UNWTO (2011), UNWTO Tourism Highlights, [online] viewed 08 January 2019, http://mkt.unwto.org/sites/all/files/docpdf/unwtohighlights1 1enhr.pdf

United Nations World Tourism Organization UNWTO (2012), UNWTO Tourism Highlights, [online] viewed 08 January 2019, http://mkt.unwto.org/sites/all/files/docpdf/unwtohighlights 12enhr.pdf

United Nations World Tourism Organization UNWTO (2015), UNWTO Tourism Highlights, [online] viewed 08 January 2019, https://www.e-unwto.org/doi/pdf/10.18111/9789284416899

United Nations World Tourism Organization UNWTO (2016), Tourism Barometer, [online] viewed 08 January 2019, http://cf.cdn.unwto.org/sites/all/files/pdf/unwto_barom17_03 june_excerpt_1.pdf

United Nations World Tourism Organization UNWTO, United Nations Environmental Programme UNEP and World Metereological Organisation WMO (2008) Climate Change and Tourism: Responding to Global Challenges, [online] viewed 08 January 2019 , https://sdt.unwto.org/sites/all/files/docpdf/climate2008.pdf

United Nations' World Commission on Environment and Development UNWCED (Brundtland Commission) (1987) Our common future (The Brundtland Report). [online] viewed 18 January 2019, http://mom.gov.af/Content/files/Bruntland_Report.pdf

Williams, M.A., Michael C.H. (2002), "Tourism, Migration, Circulation and Mobility: The Contingencies of Time and Place", in Hall C.M. and Williams A.M. (eds.) Tourism and Migration - New Relationships between Production and Consumption, Kluwer Academic Publishers, Dordrecht.

World Committee on Tourism Ethics and UNWTO (2005), The Responsible Tourist and Traveller A/RES/506(XVI) [online] viewed 14 January 2019, http://ethics.unwto.org/sites/all/files/docpdf/responsibletouristtexten.pdf

WTTC (2016), Tourism as a driver of peace, [online] viewed 02 February 2019 https://sp.wttc.org/-/media/files/reports/special-and-periodic-reports/tourism-as-a-driver-ofpeace_full-report---web.pdf?la=es

Yanez-Arancibia, A., Davalos-Sotelo, R., Day, J.W., Reyes, E. (2013), Ecological dimensions for sustainable socio economic development, WIT Press, Southampton.

Yeoman, I., Andrade, A., Leguma, E., Wolf, N., Ezra, P., Tan, R., McMahon-Beattie, U. (2015), “2050: New Zealand's sustainable future", Journal of Tourism Futures, Vol. 1, Issue 2, pp. 117-130.

Zaidan, E.A., Wall, G. (2013), Mobility, migration and tourism [online] viewed 08 February 2019 , https://www.researchgate.net/publication/292428449_Mobility_migration_and_tourism 
ToSEE - Tourism in Southern and Eastern Europe, Vol. 5, pp. 489-505, 2019

M. Nikšić Radić, D. Gračan, M. Barkiđija Sotošek: AGE OF MIGRATION: A CHANCE FOR ...

Maja Nikšić Radić, PhD, Assistant Professor

University of Rijeka

Faculty of Tourism and Hospitality Management

Department of International Economics and Development

Primorska 42, 51410 Opatija, Croatia

Phone: +385-51-294716

E-mail: majanr@fthm.hr

Daniela Gračan, PhD, Full Professor

University of Rijeka

Faculty of Tourism and Hospitality Management

Department of International Economics and Development

Primorska 42, 51410 Opatija, Croatia

Phone: +385-51-294718

E-mail: danielag@fthm.hr

Marina Barkiđija Sotošek mag. oec.

University of Rijeka

Faculty of Tourism and Hospitality Management

Department of International Economics and Development

Primorska 42, 51410 Opatija, Croatia

Phone: +385-51-294718

E-mail: marinab@fthm.hr 